\title{
Living Arrangements and Aging in Mexico: Changes in Households, Poverty and Regions, 1992-2009
}

\author{
Verónica Montes de $\mathrm{Oca}^{1}$, Sagrario Garay ${ }^{2}$, Brittany Rico ${ }^{3} \&$ San Juanita García ${ }^{3}$ \\ ${ }^{1}$ Universidad Nacional Autónoma de México, Mexico \\ ${ }^{2}$ Universidad Autónoma de Nuevo León, Mexico \\ ${ }^{3}$ Texas A\&M University, USA \\ Correspondence: Verónica Montes de Oca, Universidad Nacional Autónoma de México, Mexico
}

Received: July 2, 2014

Accepted: July 21, 2014

Available online: August 29, 2014

doi:10.11114/ijsss.v2i4.453

URL: http://dx.doi.org/10.11114/ijsss.v2i4.453

\begin{abstract}
This paper analyzes diverse socio-demographic variables in living arrangements among older people at national and regional levels in Mexico. Using the National Survey of Demographic Dynamics for 1992, 1997, 2006 and 2009, we develop two levels of analysis, household and individual, in order to show trends and changes in composition of households in Mexico focusing on those including elderly people. A multinominal logistic model was used to determine the effect of diverse variables on living arrangements. The findings show an increase in the percentage of households with elderly people living alone; at a regional level, the Yucatán Peninsula has the lowest percentage of elderly households; old men are more likely to live in nuclear and extended families than women; people aged 80 and older currently employed have greater probabilities of living alone.
\end{abstract}

Keywords: households, aging, regions, living arrangements.

\section{Introduction}

The demographic transition in Mexico is leading to an aging population. The decrease in mortality and fertility rates and increase in life expectancy have transformed households, thus becoming an important aspect when planning public policies. In 1930 the mortality rate was 26.7 deaths for each one 1000 inhabitants; in 2000 this indicator was 5.1 and 5.6 deaths for each one 1000 inhabitants in 2010 (Instituto Nacional de Estadística y Geografía [INEGI] 2010). The global fertility rate in 1930 and 2010 were 6 and 2.1 children for women in reproductive age, respectively (INEGI 2010). The life expectancy in the same period was 34.7 years in 1930 and 75 years in 2010 (77 years for women and 73 years for men) (INEGI 2010). According with this demographic process, the main objective of this article is to present some of these transformations at both a national and regional level, as well as showcasing the influence of diverse socio-demographic characteristics on the types of households for the elderly population.

As the population ages, individuals' economic and healthcare also needs increase. It is therefore essential to analyze the demographic, economic, and social characteristics of households. Using the National Survey of Demographic Dynamics, we analyze the most important changes in Mexican households from 1992 to 2009, giving emphasis to households including residents 60 and older. We also seek to understand the underlying motivations that influence the elderly population's decisions for living in a certain type of household.

One aspect that we wish to highlight is the relation between composition of households and socioeconomic status (SES) and the regional distribution of the different types of households within the country. The literature has made it clear that families in Mexico choose to live together in order to optimize resources, but the situation concerning households which include the elderly has not been fully explored (Ramos 1994). We therefore examine the trends in Mexican households over the last two decades and the percentage of elderly households in different regions of Mexico over time.

This paper is divided into four sections. First, we deal with general aspects regarding the concepts of households and families in Mexico. Then we present the data and methods of the study. Next, we show the changes in distribution of various living arrangements in the years 1992, 1997, 2006 and 2009, differentiating among the total number of households, particularly, those in which the elderly are present and those where there are elderly and children under 5 years of age. Next, we analyze the composition of these households by SES and region of the country over the same 
periods. Finally, we discuss the main characteristics of the population that live in households including individuals aged 60 and older, as well as the influence of various individual, family, and contextual characteristics of the aging population residing in each type of living arrangement.

In Mexican culture, families represent the fundamental institution for social reproduction, healthcare, and social support. One way to understand Mexican family dynamics has been through the study of households or domestic units. The household is defined as "the social sphere in which people, related or not, share a residence and organize their daily lives" (Oliveira 1988: 22). Although, in theory, family and household are different concepts, the use of household as a unit of analysis in sources of secondary information has been a useful tool for the study of the family (Echarri-Cánovas 1995; López-Barajas and Izazola 1994; López-Ramírez and Lindstrom 2008; Pérez-Amador and Brenes 2006). From this focal point, the analysis of individuals as aggregates living in the same dwelling and sharing common expenses is what identifies and distinguishes the household or domestic unit (García, Muñoz and Oliveira 1988; Tuirán 1996) from 'family'. This has allowed for the visualization of transformations and trends in households as living arrangements and their compositions at different times throughout history, as well as different periods in the family life cycle. Understanding these changes is pertinent in the context of broader demographic transformations, such as those which are a result of an increased life expectancy and demographic aging.

\section{Data and Method}

In this paper, we use the National Survey of Demographic Dynamics (ENADID) for the years 1992, 1997, 2006 and 2009 as a database providing a representative reference of changes in household composition at national and regional levels.

There are two levels at which the data from this type of survey can be analyzed: the household unit and/or the individuals who reside in the household. In our case we consider both units of analysis. At the first level of analysis we are interested in pointing out changes in households over the last decade. This type of analysis requires the construction of databases from which a traditional typology of households may be formed: nuclear, extended, compound, one-person and co-residence (Diagram 1) (Instituto Nacional de Estadística Geografía [INEGI] 1997). Within this typology, the diversity of arrangements existing within households is taken into consideration

Diagram 1 Family Households

\begin{tabular}{|c|c|}
\hline $\begin{array}{c}\text { Nuclear } \\
\text { Household }\end{array}$ & $\begin{array}{l}\text { - Couple alone } \\
\text { - Couples with single children }\end{array}$ \\
\hline $\begin{array}{c}\text { Extended } \\
\text { Household }\end{array}$ & $\begin{array}{l}\text { - Couple without children and other relatives } \\
\text { - Couple with children and other relatives (including couple with single } \\
\text { and married children) } \\
\text { - Head and other relatives }\end{array}$ \\
\hline $\begin{array}{l}\text { Compound } \\
\text { Household }\end{array}$ & $\begin{array}{l}\text { - Couples without children and other non-relatives (including domestic } \\
\text { workers) } \\
\text { - Couples with children and other non-relatives (including couples with } \\
\text { single children, married or cohabiting children and domestic workers) }\end{array}$ \\
\hline $\begin{array}{l}\text { One-person } \\
\text { Household }\end{array}$ & - $\quad$ Head alone \\
\hline $\begin{array}{l}\text { Co-resident } \\
\text { Household }\end{array}$ & - Head and non-relatives (including domestic workers) \\
\hline
\end{tabular}

Source: Instituto Nacional de Estadística y Geografía (1997). Los hogares en México, Mexico City: INEGI.

Due to our interest in the elderly population, this study focuses on the individuals residing in these households. We use a multinomial logistic regression model, as this allows us to include more than two categories as independent variables. The dependent variable is the type of living arrangements; with the reference group representing nuclear households with older persons as this type of household is the most common in Mexico. The independent variables are: sex, age, employment status, presence of immigrants in the household, and size of locality. Also, we use a multinomial logistic regression model as it allows us to explain the effect of a specific variable while keeping the other factors constant 
(Borooah 2002).

\section{Results}

\subsection{Households in Mexico 1992-2009: trends in aging}

The demographic changes Mexico has experienced, such as longer life expectancy and a lower global fertility rate, have resulted in an increase in the aging population. In Mexico, as in other countries, this has altered family dynamics in several ways, such as the relations of intergenerational exchange; family coexistence; distribution of care giving among its members; as well as a series of adjustments related to the satisfaction of the needs of the younger and older generations (Ferring 2009; Gomes 2007; Gomes and Montes de Oca 2004; Grundy and Henretta 2006; Katz 2009; Palloni, Pinto and Wong 2009). However these are not the only changes that have had an impact on households. There are also other factors, that include age at marriage (e.g. age at first marriage, consensual unions, separations or divorces) and women's education and participation in the labor market (García and Rojas 2002).

These changes in family dynamics have led to new forms of organization within households in Mexico. In general point of view, these include a reduction in the size of households; a relative decrease in the number of nuclear households; an increase in the number of non-nuclear households; an increase in the number of single, married, divorced or widowed female headed households; "aging" of households; and economic responsibilities shared by men and women (López-Ramírez 2001).

Some of the changes in household composition are shown at the national level between 1992 and 2009 (Graph 1). Nuclear households have decreased in relative importance while, among these, the percentage of couples living alone or heads of households living alone with their children has increased. Extended households have not experienced significant changes, except in the period of 2006-2009; among these types of households there was a reduction of couples living with their children and other relatives (Montes de Oca and Garay 2010). One aspect that stands out is the increase in one-person households, especially in the period of 2006-2009.

Graph 1. Types of households in Mexico, 1992 - 2009 (percentages)

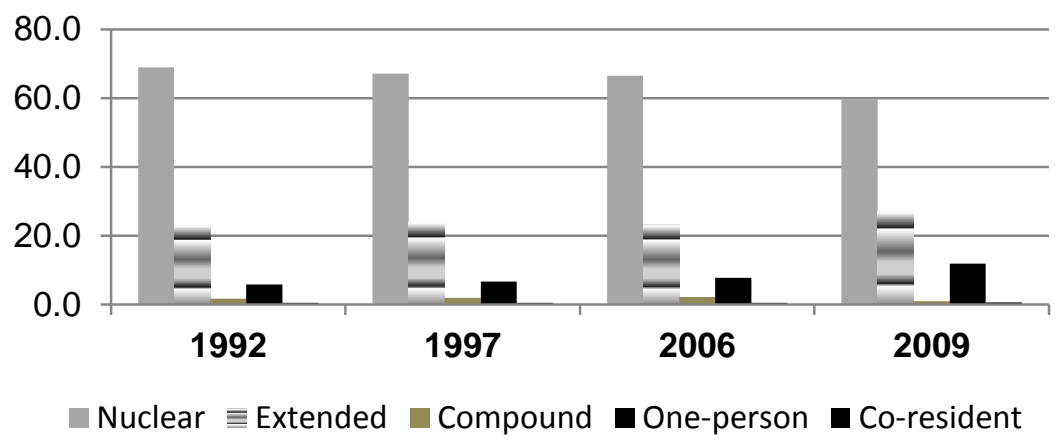

Source: Own calculations with National Survey of Demographic Dynamics (ENADID) 1992, 1997, 2006 and 2009.

\subsection{Older Persons in Households in Mexico}

With respect to households including people who are 60 years and older, the data reveals a slight increase between 1992 and 2009 , from $24.2 \%$ to $29.2 \%$. At the same time there was a marked decrease in the proportion of households with residents less than five years of age: in 1992 this group accounted for $47 \%$, while in 2009 it decreased to $30 \%$. This is simply a reflection of the decrease in fertility rates and increase in life expectancy rates. The change in Mexican households represents not only a transformation in structures by age and generational composition, but also reflects the changes in priorities of Mexican families (Rabell and Murillo 2010).

A vast literature on households and aging exists stemming from a growing consciousness on demographic aging. These studies focus on analyzing the composition of households with elderly members, as well as the residential situation and family dynamics of the elderly individual. Nationally, findings show that the predominant types of households among the elderly are nuclear and extended, with a significant presence in single-person households (López and Izazola 1994; INEGI 1997). Although these trends persist, the following changes between 1992 and 2009 are worth highlighting: the proportion of nuclear households with at least one elderly individual has decreased from 39 percent in 1992 to 36.4 percent in 2009. The percentage of extended households with elderly individuals does not show much variation, except in 2006, which shows a significant reduction. The most significant change occurs in single-person households, which have been on the rise since the 1990s, and, particularly in the last decade (Table 1). 
Table 1. Types of Households with Members over 60 in Mexico, 1992 - 2009 (percentages)

\begin{tabular}{lrrrr}
\hline & $\mathbf{1 9 9 2}$ & $\mathbf{1 9 9 7}$ & $\mathbf{2 0 0 6}$ & $\mathbf{2 0 0 9}$ \\
\hline Family Household & $\mathbf{8 6 . 3}$ & $\mathbf{8 5 . 7}$ & $\mathbf{8 3 . 4}$ & $\mathbf{8 2 . 6}$ \\
Nuclear & $\mathbf{3 9 . 0}$ & $\mathbf{3 7 . 7}$ & $\mathbf{4 2 . 3}$ & $\mathbf{3 6 . 4}$ \\
$\quad$ Couple alone & 13.0 & 11.9 & 17.4 & 14.4 \\
Couples with children single & 19.2 & 18.5 & 16.3 & 15.8 \\
$\quad$ Head with children single & 6.7 & 7.2 & 8.6 & 6.2 \\
Extended & $\mathbf{4 7 . 3}$ & $\mathbf{4 8 . 0}$ & $\mathbf{4 1 . 0}$ & $\mathbf{4 6 . 3}$ \\
$\quad$ Couple without children and other & & & & \\
relatives & 4.4 & 3.7 & 4.5 & 3.8 \\
$\quad$ Couple with children and other relatives & 26.5 & 26.4 & 19.0 & 23.3 \\
$\quad$ Head and other relatives & 6.1 & 6.1 & 6.4 & 5.8 \\
$\quad$ Head with children and other relatives & 10.2 & 11.8 & 11.1 & 13.4 \\
Non Family Households & $\mathbf{1 3 . 7}$ & $\mathbf{1 4 . 3}$ & $\mathbf{1 6 . 6}$ & $\mathbf{1 7 . 4}$ \\
Compound & $\mathbf{1 . 8}$ & $\mathbf{2 . 2}$ & $\mathbf{2 . 5}$ & $\mathbf{1 . 1}$ \\
Couples without children and other not relatives & 0.3 & 0.4 & 0.5 & 0.1 \\
Couples with children and others not relatives & 0.9 & 1.2 & 1.2 & 0.4 \\
$\quad$ Head with children and other relatives & 0.4 & 0.4 & 0.6 & 0.5 \\
$\quad$ Head with relatives and no relatives & 0.2 & 0.3 & 0.2 & 0.1 \\
One-person & $\mathbf{1 1 . 5}$ & $\mathbf{1 1 . 7}$ & $\mathbf{1 3 . 8}$ & $\mathbf{1 6 . 0}$ \\
Co-resident & $\mathbf{0 . 5}$ & $\mathbf{0 . 4}$ & $\mathbf{0 . 3}$ & $\mathbf{0 . 3}$ \\
$\quad$ TOTAL & 100.0 & 100.0 & 100.0 & 100.0 \\
$\quad$ N & 13788 & 17162 & 9620 & 24562 \\
\hline
\end{tabular}

Source: Own calculations with National Survey of Demographic Dynamics (ENADID) 1992, 1997, 2006 and 2009.

Non-family households have increased in an important manner, one-person units being the ones driving this increase (Table 1). There are studies that point towards the growing tendency to prefer to live out one's old age in independence of the rest of the family, although there has also been speculation that this is due to a higher level of education in the new generations of aging adults and in autonomy of decision making and financial management (Coward and Cutler 1991; Coward, Cutler and Schmitd 1989; Ramos 1994; Wilhite 1994).

It has also been observed in the literature on family demographics that one effect of a reduction in mortality is a greater tendency for more than two generations to be found living together. ${ }^{1}$ However, these types of households were $6 \%$ in $1992,5.7 \%$ in 1997 and $5.5 \%$ in 2009 . It is worth pointing out that as the percentage drops the absolute number of households with these characteristics has also diminished in the same time period. The percentages of extended households units decreased in 2009. Nuclear households with children under 5 and older adults increased to $10.9 \%$ in $2009^{2}$ (Table 2)

Table 2. Households with members < 5 year old and elderly individuals, Mexico, 1992- 2009 (percentages)

\begin{tabular}{lcccc}
\hline & $\mathbf{1 9 9 2}$ & $\mathbf{1 9 9 7}$ & $\mathbf{2 0 0 6}$ & $\mathbf{2 0 0 9}$ \\
\hline Nuclear & 5.5 & 3.6 & 2.7 & 10.9 \\
Extended & 91.6 & 92.5 & 90.0 & 87.5 \\
Compound & 2.9 & 3.8 & 7.1 & 1.6 \\
Co-resident & 0.0 & 0.1 & 0.1 & 0.0 \\
\hline \multicolumn{1}{c}{ TOTAL } & 100.0 & 100.0 & 100.0 & 100.0 \\
\hline \multicolumn{1}{c}{$\mathrm{N}$} & $(3383)$ & $(3986)$ & $(1517)$ & $(4598)$ \\
\hline
\end{tabular}

Source: Own calculations with National Survey of Demographic Dynamics (ENADID) 1992, 1997, 2006 and 2009.

\footnotetext{
${ }^{1}$ Some authors point out that this practice can result in benefits to the younger generations in the form of additional human capital and possibilities for childcare (Rentería, Maldonado and Lanza 2007).

${ }^{2}$ In 2009, the percentage of older men who reside in households with people under 5 is much higher than that of older women, $61.1 \%$ vs. $38.9 \%$. When the relationships between members of such households is further explored, it is found that the presence of young children does not always correspond to grandchildren. Rather, a proportion of the co-residence of young children and aging adults in the same household is related to a man's second marriage to a younger woman, with resulting offspring.
} 
The different living arrangements with children under 5 plus individuals 60 years and older include households with a higher degree of co-residence between generations and, on a local level, as an effect of out-migration. In these households the adult members can be subject to a double generational pressure, derived from both descendants and ascendants, since both two groups impose specific demands such as healthcare and nutritional needs. Additionally it is not easy to find these homes in a formative or dissolutive stage because their kinship relationship is one of grandparents and grandchildren and parents and children. It is also a type of household derived from the dynamics of the job market, remarriage between older men with younger women, be it from out-migration or due to the fact that household members need extra hands to care for the young or sick. This job is on many occasions left to grandmothers, who make up for the shortage of day care facilities in Mexico (Caballero et al. 2008; Gomes and Montes de Oca 2004).

In summary, the information presented shows significant differences in the household structures of the total population nationwide as regards households with individuals 60 years and older. Although one-person households are not statistically significant on a national level, they become important when only the senior population is considered. Among households with populations 60 years and older, there has been an increase in one-person households and a decrease in the number of nuclear and extended households until 2006, the one-person households continued to grow in 2009.

\subsection{Households with Older Persons and Poverty}

The previous section can be complemented with information about households of older persons and SES. In Mexico, nuclear households show a tendency to higher SES. This trend increased between 1992 and $2006^{3}$ (Table 3). In the composition of this type of living arrangement, the proportion of couples in the mid-SES category has increased considerably along with the lower SES category. This shows the highest percentages in this category. In the higher SES category there is a greater percentage of two-parent households with children, as well as heads of families who live alone with their children, the latter showing a sizeable increase between 1992 and 2006. This could be a consequence of the phase in which the family life cycle finds itself at the time, since it could be considered that among unmarried siblings there are more economically active members. This aspect becomes more evident when compared to households with elderly members, where this effect is clearly visible (Montes de Oca and Garay 2010).

As has been observed in other studies, the incidence of extended households with senior men and women is higher in the lower SES category. This rate has fallen in the different social SES categories between 1992 and 2006 but has shown a greater decrease in the middle SES category, particularly, among couples with children and other relatives (Table 3). When households with children under 5 years of age and elderly are observed, it is noted that most of these domestic units are extended, which is prevalent in the lower SES. ${ }^{4}$ Within these types of households the category of couples with children and other relatives fell considerably between 1992 and 2006 in the middle and higher SES, decreasing from $64.9 \%$ to 54.6\% respectively (Montes de Oca and Garay 2010). At the same time, living arrangements where the head of the family lives alone with children and other relatives has gained presence among all SES categories, increasing from $17.8 \%$ to $23 \%$ in the lower SES and from $21.9 \%$ to $30.5 \%$ in the middle and higher SES for the 1992 to 2006 period.

The literature on aging has indicated that it is mainly elderly women who form one-person households which make them more susceptible to vulnerable situations (Varley and Blasco 1999). ${ }^{5}$ While Ramos (1994) found that in Brazil such elderly people live in better conditions than those who live in multigenerational households, in the case of Mexico we have found a very different outcome for elderly people living alone, a situation to which this paper calls attention. Since 1992, a higher concentration of one-person households has been found in the lowest SES, this relative presence increased towards 1997 and then decreased slightly in 2006. Nevertheless, the National Survey for Demographic Dynamics (ENADID) for 2006 shows that one-person households are also concentrated in the lower and middle SES categories. This is most likely due to the consequence of new programs for monetary transference focusing on assisting older persons (Table 3).

\footnotetext{
${ }^{3}$ In 2009 the ENADID did not include SES as a variable; we could not therefore recode it since the methodology for the elaboration of the SES variable in previous years is not available to the public.

${ }^{4}$ For households with aging residents and children under 5, four socioeconomic strata were grouped in two due to fact that the number of cases was significantly reduced when divided into the four strata.

${ }^{5}$ In the case of Mexico there is no significant association between SES and sex, which is why the economic situation is very similar for men and women 60 or older; both tend to find themselves in the less advantaged socioeconomic strata.
} 
Table 3. Households with Older Persons by Socioeconomic Status, Mexico, 1992 - 2006 (percentages)

\section{Very low Low Medium High}

\begin{tabular}{lcccc}
\hline $\mathbf{1 9 9 2}$ & & & & \\
Nuclear & 39.8 & 34.8 & 41.5 & 45.2 \\
Extended & 42.4 & 57.7 & 45.4 & 42.9 \\
Compound & 0.8 & 1.9 & 2.5 & 6.4 \\
One-person & 16.8 & 5.3 & 9.9 & 2.7 \\
Co-resident & 0.3 & 0.3 & 0.6 & 2.7 \\
Total & 100.0 & 100.0 & 100.0 & 100.0 \\
1997 & & & & \\
Nuclear & 39.8 & 34.0 & 37.3 & 41.7 \\
Extended & 39.7 & 56.4 & 50.0 & 48.9 \\
Compound & 1.4 & 1.9 & 2.4 & 5.5 \\
One-person & 18.8 & 7.3 & 9.8 & 3.2 \\
Co-resident & 0.3 & 0.4 & 0.5 & 0.8 \\
Total & 100.0 & 100.0 & 100.0 & 100.0 \\
2006 & & & & \\
Nuclear & 42.7 & 32.8 & 47.3 & 52.2 \\
Extended & 38.1 & 53.2 & 33.7 & 37.8 \\
Compound & 1.6 & 3.4 & 2.1 & 4.0 \\
One-person & 17.4 & 10.3 & 16.6 & 5.5 \\
Co-resident & 0.2 & 0.3 & 0.3 & 0.6 \\
Total & 100.0 & 100.0 & 100.0 & 100.0 \\
\hline
\end{tabular}

Source: Own calculations with National Survey of Demographic Dynamics (ENADID) 1992, 1997 and 2006.

The differences in SES and the higher percentage of households with elderly members are the result of their distribution within national territory. Throughout the country there are areas of high marginalization and structural poverty which have previously been reported by Mexican institutions (Consejo Nacional de Población [CONAPO] 2006).

\subsection{Households with older persons in regions of Mexico}

The changes observed at national level regarding households with elderly populations become much more pronounced when certain regions of the country are compared to each other. ${ }^{6}$ In 1992, it was observed that the number of households with senior members were concentrated in the country's North, Central Western, Central Eastern and Southern regions (Map 1). ${ }^{7}$ Amongst these, the Central Eastern region had the highest percentage, with 26.8 percent of the households having at least one person aged 60 or older. At the same time, in 1992 the regions with percentages below the national level were the North Western, North Eastern, Center, Eastern and the Yucatan Peninsula; the latter region also presented the lowest relative number of households with elderly populations, 21.7\% (Map 2).

\footnotetext{
${ }^{6}$ The regions considered by the ENADID are: North Western, North, North Eastern, Central Western, Central Eastern, Southern, Center, Eastern and the Yucatan Peninsula (Map 1).

${ }^{7}$ To distinguish the degree of concentration of households with people over 60 years in the different regions, those regions with a concentration similar or higher than the national level were classed as high, those below the national average as low.
} 
Map 1. Mexico: regional division

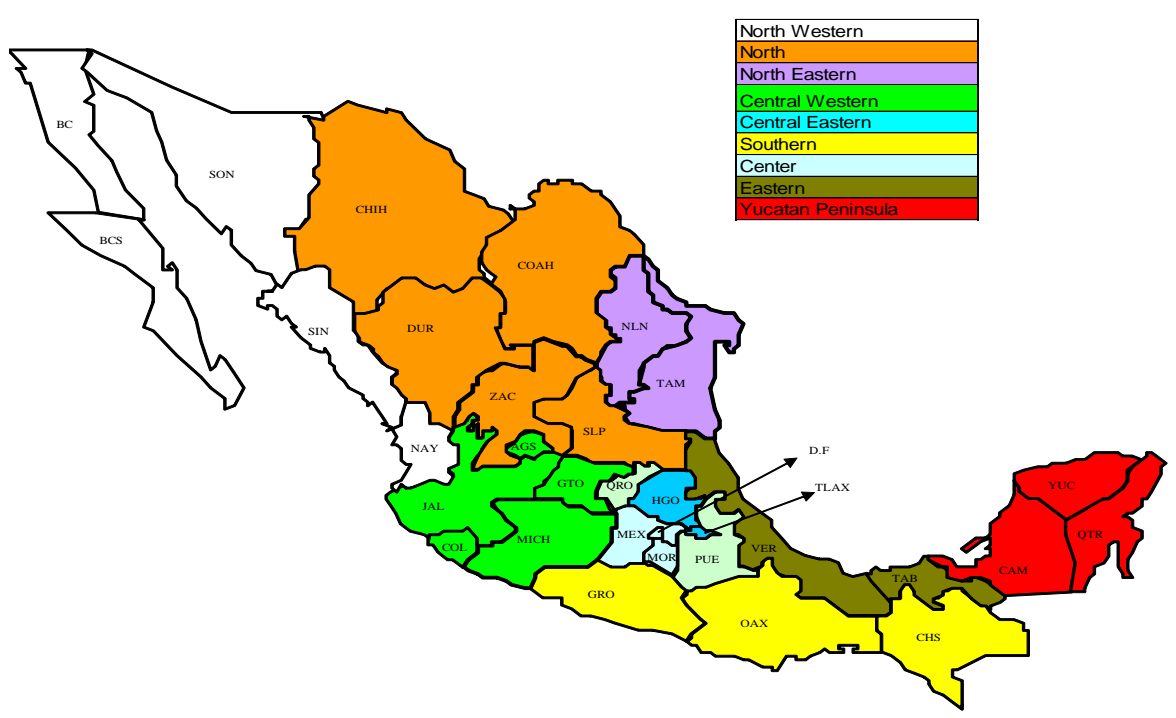

In 1997, the regional panorama did not register many changes in terms of distribution, it is worth noting that only the Center region's percentages have surpassed those of the national average since 1992 (Map 3). The Central Eastern region had the highest concentration of elderly households (27.6\%) in 1997. The Yucatan Peninsula has remained the region with the lowest proportion of households containing people aged 60 and older (20.8\%).

By 2006 some important changes had occurred. The North Eastern region, where proportions had remained below the national average in 1992 and 1997, now had the highest percentage of households with elderly people. On the other hand, the Central, Eastern and Southern regions, which were above the national average, showed for 2006 proportions lower than those of the whole country. The Yucatan Peninsula maintains the lowest proportion of households with populations aged 60 and older (Map 4).

Again, interesting changes were taking place in 2009. The regions with the highest percentage of households with older adults at national level were North Eastern, North, Central Western and Southern (Map 5). These regions accelerated their aging rate compared to others, but all regions have had a very marked decline in fertility as evident in the percentage of households with children under 5 (Graph 2 and Graph 3).

Map 2

Households with older persons in Mexico, 1992

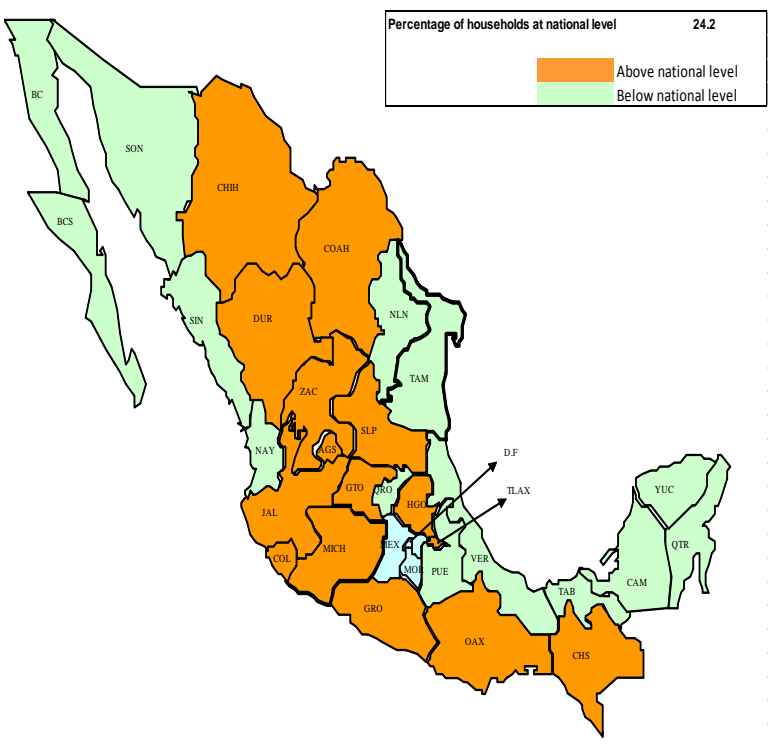

Map 3

Households with older persons in Mexico, 1997

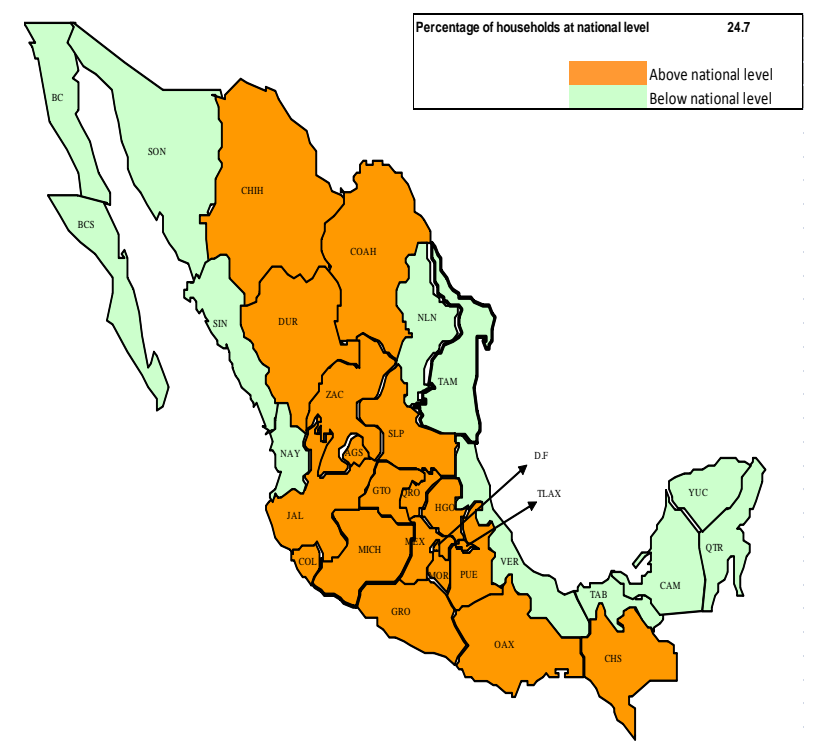


Map 4

Households with older persons in Mexico, 2006

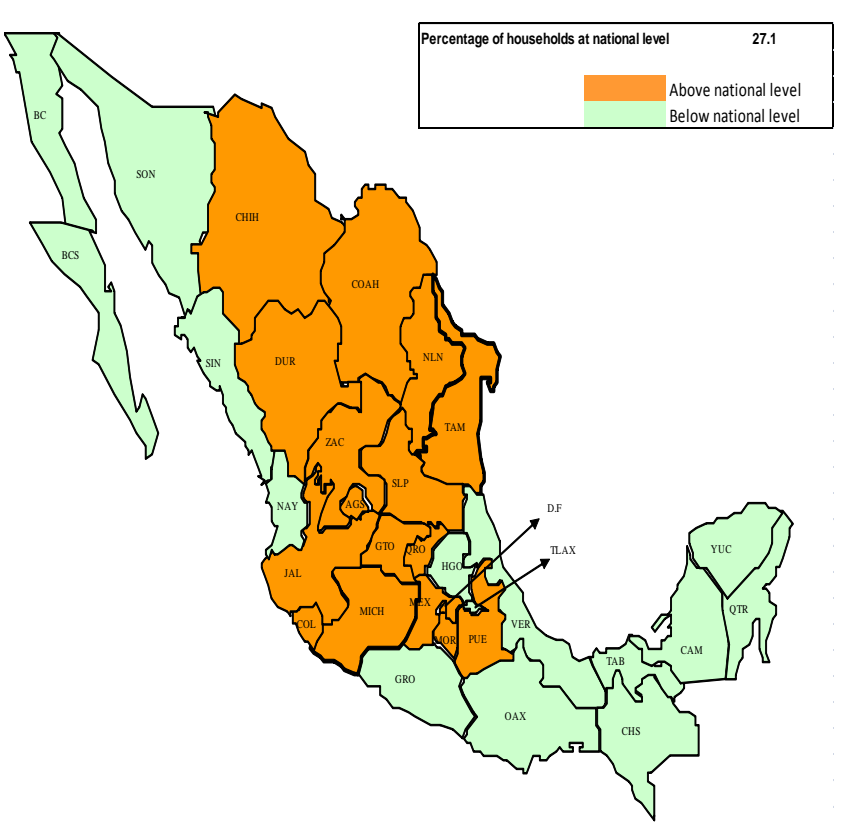

Map 5

Households with older persons in Mexico, 2009

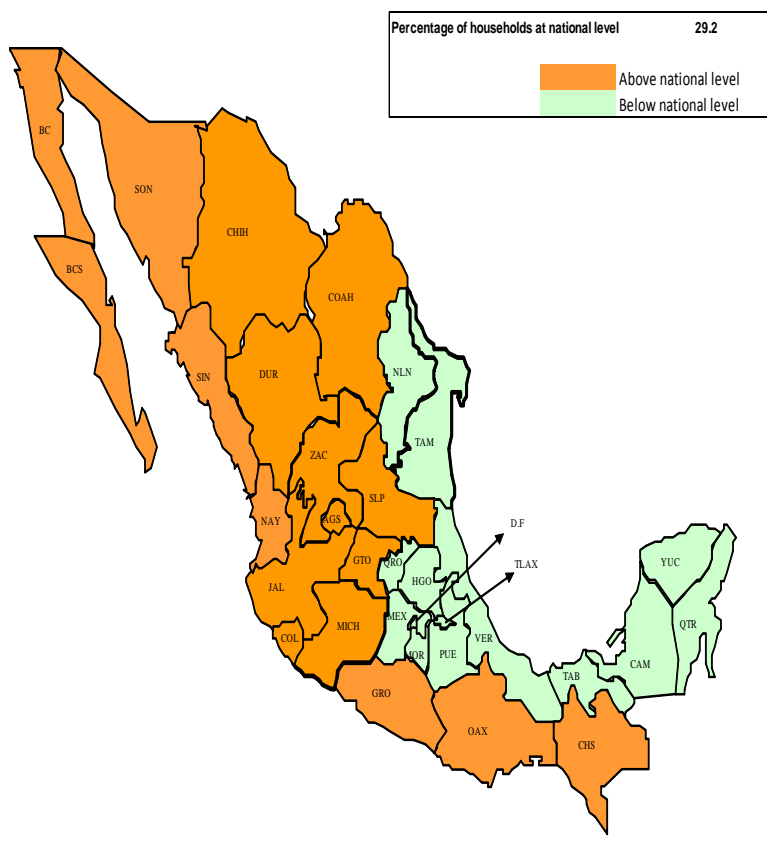

Source: Own calculations with National Survey of Demographic Dynamics (ENADID) 1992, 1997, 2006 and 2009

Interestingly, from 1992 to 2009 the North region continuously had a higher rate of households with aging populations, whereas the Central Eastern and Southern regions had a higher rate of households with children under 5 and of households with both children and elderly people (Graph 2 and Graph 3). This is due to the higher rate of aging in the North region of the country (Ruíz-Pantoja 2008). Also, the differentiated fertility rates for the country regions provide insight into this phenomenon. For example, in the Southern region the fertility rate is high, while in the Central and North regions it has dropped and life expectancy has increased (Table 4).

Table 4. Fertility rates and life expectancy by region in Mexico, 2010

\begin{tabular}{lcc}
\hline Center & Fertility rates & Life expectancy \\
\hline Distrito Federal & 1.80 & 75.49 \\
México & 2.23 & 74.45 \\
Morelos & 2.20 & 74.72 \\
Puebla & 2.53 & 74.00 \\
Querétaro & 2.24 & 74.68 \\
\hline Central Western & \\
\hline Aguascalientes & 2.55 & 75.19 \\
Colima & 2.26 & 75.25 \\
Guanajuato & 2.37 & 74.66 \\
Jalisco & 2.32 & 74.76 \\
Michoacán de Ocampo & 2.38 & 73.84 \\
\hline Central Eastern & & \\
\hline Hidalgo & 2.38 & 73.62 \\
Tlaxcala & 2.39 & 74.34 \\
\hline North & & \\
\hline Coahuila de Zaragoza & 2.31 & 74.71 \\
Chihuahua & 2.31 & 68.68 \\
Durango & 2.38 & 73.92 \\
San Luis Potosí & 2.48 & 73.76 \\
Zacatecas & 2.46 & 74.31 \\
\hline North Western & 2.01 & \\
\hline Baja California & &
\end{tabular}




\begin{tabular}{llc} 
Baja California Sur & 2.00 & 75.50 \\
Nayarit & 2.25 & 73.86 \\
Sinaloa & 2.29 & 73.84 \\
Sonora & 2.32 & 74.52 \\
\hline North Eastern & \\
\hline Nuevo León & 2.13 & 75.79 \\
Tamaulipas & 2.21 & 74.72 \\
\hline Southern & & \\
\hline Chiapas & 2.70 & 71.95 \\
Guerrero & 2.69 & 71.91 \\
Oaxaca & 2.56 & 71.93 \\
\hline Eastern & \\
\hline Tabasco & 2.31 & 73.99 \\
Veracruz de Ignacio de la Llave & 2.19 & 73.29 \\
\hline Yucatan Peninsula & & \\
\hline Campeche & 2.14 & 74.64 \\
Quintana Roo & 2.05 & 74.95 \\
Yucatán & 2.27 & 74.90 \\
\hline
\end{tabular}

Source: Indicadores demográficos básicos 1990-2010. Consejo Nacional de Población, www.conapo.gob.mx

Graph 2. Regional distribution of elderly person households in Mexico, 1992 - 2009

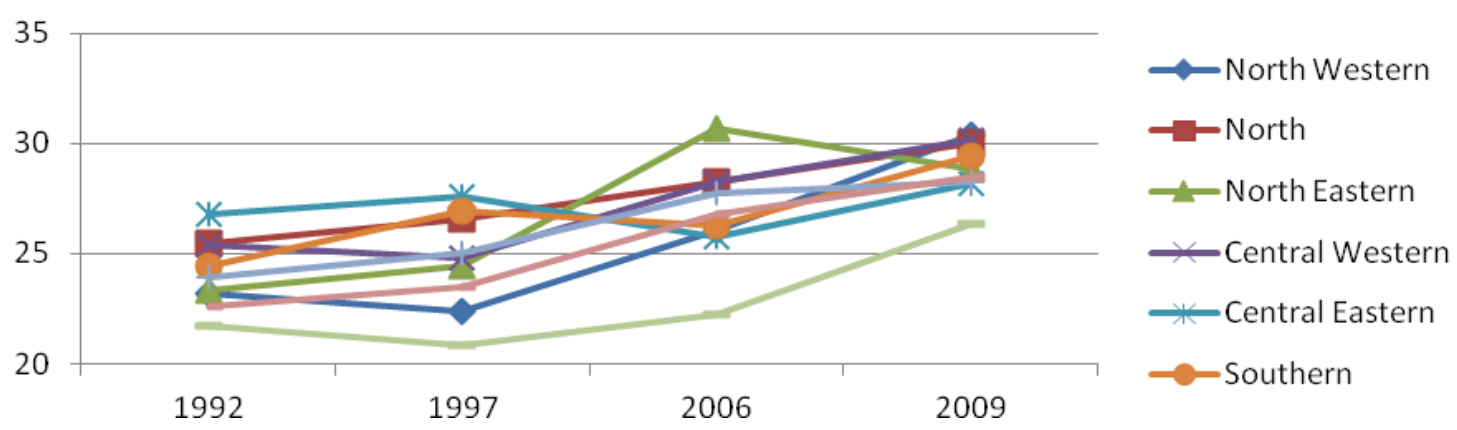

Graph 3. Regional distribution of households with $<5$ years olds in Mexico, $1992-2009$

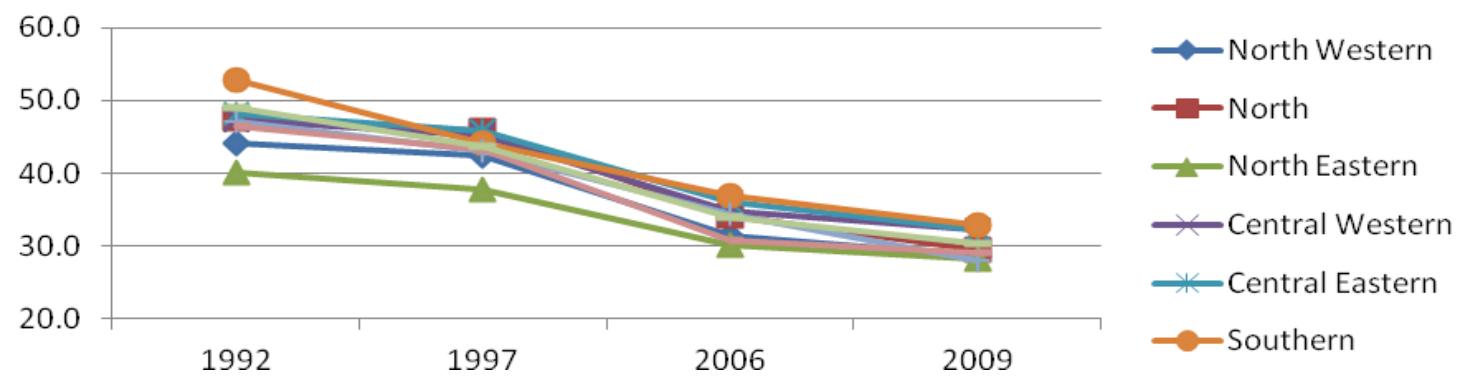

Source: Own calculations with National Survey of Demographic Dynamics (ENADID) 1992, 1997, 2006 and 2009.

At national level it has been shown that the SES of the population aged 60 and older and their households are not encouraging. A large number of these households find themselves in an unfavorable situation. For example, in 1992, of the $26.8 \%$ of households in the Central Eastern region, $80 \%$ were in the lower SES category. Similarly in the Southern region, $87 \%$ of households with elderly residents were living in poverty. In $1997,75 \%$ and $80 \%$ of households with aging inhabitants in the Central Eastern and Southern regions, respectively, suffered unfavorable socio-economic conditions. These results were to be expected, especially in the Southern region, due to the fact that historically this region has had the highest concentration of poverty in the country (Esquivel 1999).

The situation looks more favorable for 2006, when $15 \%$ and $17 \%$ of households came into the higher SES category in the North and Central regions, respectively. This was expected since these are the regions with greatest socioeconomic development in the country (Esquivel 1999; Messmacher 2000). It is important to remember that in this year the Central Eastern and Southern regions do not appear as areas with a high concentration of households with older persons.

Just as households vary by SES, the predominant living arrangements for the elderly also differ by region. As a result of 
our analysis we are able to better visualize the types of households with residents aged 60 and older. In 1992, there was a higher presence of nuclear households in the North, North Western, North Eastern and Central Western regions. This type of living arrangement became less common in 2006, and only in the Central Western and North Eastern regions did the nuclear household remain dominant over the extended arrangement (Montes de Oca and Garay 2010).

Among the various regions, the Central Eastern, Southern, Central, Yucatan Peninsula and Eastern regions had a higher incidence of elderly members within extended households. These regions are characterized by high rates of marginalization, poverty, and low life expectancies (except, in the central region, in Mexico City). A possible strategy of these families with elderly people is to live in multi-generational households. In the North region there is a greater presence of households with couples living with an elderly member. This living arrangement is seen as a common and economically feasible way to deal with health related issues to maintain quality of life in old age (Montes de Oca and Garay 2010).

Generally, one-person elderly households in the North and Northwestern regions are associated with better SES, but we could not say the same about those found in the Southern Region or the Yucatan Peninsula. Specifically in the states of Guerrero, Oaxaca and Chiapas the living conditions of the elderly are closer to food poverty ${ }^{8}$. These types of one-person households are not arrangements made in order to live a better quality of life, but are, rather, a reflection of the long-run contexts of poverty, marginalization, longevity, and migration faced by these families.

In summary, there are marked differences in compositions of households with elderly people. This is a reflection of the different aging rates experienced throughout the country, resulting from different fertility and life expectancies rates. The higher aging rates experienced in the North of the country, along with higher socio-educational levels and the effects of out-migration could change the living arrangements of the elderly. In the Central Eastern, Southern and Central regions, households with elderly people tend to be extended households and there is more cohabitation with children under 5 years. In the North, households of elderly people living alone are seen to be a chosen option, whereas in the South and the Yucatan Peninsula such households are more likely to be a consequence of poverty and marginalization. In both these regions it is also impossible to overlook the role of cultural traditions, local customs, and habits (Reyes 2008).

Although we lack empirical evidence for the effect of this on households, it is important to bear in mind the violence currently permeating the country, particularly in northern Mexico. This violence may have major implications for family arrangements. More and more families choose to migrate from certain states to others or from the country and this can have two effects: it can cause an increase in extended families brought about by receiving family members who migrate internally and it can increase the number of one-person households as a result of international migration. The latter we argue is more likely to affect the older population. This however, is only a hypothesis worth mentioning here, yet which requires further investigation.

\subsection{People aged 60 years and older and their living arrangements}

One of the key interests of this paper is to show the influence of individual, family, and contextual characteristics of the aging population on the type of household arrangement in which they live. Some studies have shown that factors that influence change of households by an elderly person are the death of a spouse, illness, and the formation of families by siblings (Montes de Oca and Hebrero 2006). On this subject, we observe that unmarried elderly people are less inclined to live in extended households, followed by those who are separated or divorced (Table 5). The fact of not having a partner could be an aspect associated with residing in extended households. ${ }^{9}$

Table 5. Binomial Logistic Regression for Extended Households*, Mexico, 2009

\begin{tabular}{|c|c|c|}
\hline Marital Status & $\operatorname{Exp}(B)$ & Sig. \\
\hline Separated or divorced & 0.234 & 0.000 \\
\hline Widowers & 0.231 & 0.000 \\
\hline Single & 0.167 & 0.000 \\
\hline Married & & \\
\hline cohabiting $* *$ & 1.000 & \\
\hline
\end{tabular}

*The reference category for the dependent variable is nuclear household.**Reference category

Source: Own calculations with National Survey of Demographic Dynamics (ENADID) 2009.

\footnotetext{
${ }^{8}$ Food poverty is defined as 'the inability to afford or have reasonable access to food which provides a healthy diet' (Comité Técnico para la Medición de la Pobreza [CTMP] 2002).

${ }^{9}$ In 2009, when distinguished by sex it is shown that in extended households there is a greater presence of elderly women in this kind of arrangement (43.5\%) as compared to men (37.4\%).
} 
Interestingly, it has been pointed out that men are more inclined to live alone or with their partner; high levels of education is also related to living alone or as a couple. When older persons possess property or are in an advantageous SES position they attract new members to their household. Similarly, those who have greater economic resources are also more likely to live alone or as a couple. Elderly men or women who are working are more likely to live alone and the same is true for those with better health (Pérez-Amador and Brenes 2006; United Nations 1994) ${ }^{10}$.

Other studies not focusing on the elderly population, point out that emigration has contributed to changes in co-residence patterns (Ariza and Oliveira 2001; 2007). It is also suggested that a larger concentration of extended households exist in urban areas compared to rural (García and Rojas 2002), therefore these are other factors to consider that might influence the living arrangements of the elderly.

Taking into account the literature concerning factors influencing household arrangements, a multinomial logistic regression model $^{11}$ was run with the following independent variables: sex, age, employment status, ${ }^{12}$ presence of migrants in the household, and size of locality. Past studies suggest that these variables could have an influence on household structures and SES since this has also shown to concentrate populations into certain living arrangements (Ramos 1994; United Nations 1994; González de la Rocha 2001; Montes de Oca and Garay 2010).

Results indicate that men are less likely to live alone or in extended households, as compared to women. This confirms the idea suggested by some authors who report the adhesion of elderly women to other conjugal nuclei as a common practice in Mexican families (Montes de Oca and Hebrero, 2008). The greater presence of women in one-person households is due to an increase in life expectancy women are more likely to be widows in comparison with men (Table 6).

Also, the population 80 years and older are more likely to live in extended and one-person households, compared to those between the ages of 60 and 69, the same is true of those between the ages of 70 and 79 (Table 6). This behavior is expected for extended households but unexpected for one-person households since ageing tends to be accompanied by widowhood and decreased health, and arguably these factors have favored a change in living arrangements.

Elderly people who work are less likely to reside in an extended household as compared to those who do not. Nevertheless, while economic activity greatly increases the odds of living alone for the elderly population - and relative autonomy and independence is maintained - this does not necessarily imply better economic conditions, but rather can be considered a consequence of the lack of social security benefits (Table 6).

Some studies suggest that emigration will bring changes in living arrangements (Montes de Oca, Molina and Avalos 2008; Montes de Oca 2008). In this study it was observed that the presence of an emigrant in the household greatly increases the odds of the elderly residing in extended households in contrast to those where there are no emigrants. The opposite occurs when considering one-person households (Table 6).

The odds of living in a large household are higher for older people living in towns of less than 2,500 inhabitants (Table 6). This suggests, as indicated by several studies (INEGI 1997; González de la Rocha 2001; López 2001), that in rural settings there is a greater concentration of extended households.

Table 6. Probabilities of the elderly living in a type of household, with nuclear household as the reference category, Mexico, 200

\begin{tabular}{lrrr}
\hline & EXTENDED & ONE PERSON & NUCLEAR \\
\hline Sex & & & \\
$\quad$ Male & $37.3 *$ & $9.9 *$ & 52.8 \\
$\quad$ Female & 44.4 & 15.9 & 39.7 \\
Age & & & \\
$\quad 70$ to 79 & $39.8 *$ & $16.1 *$ & 44.0 \\
$\quad 80+$ & $42.8 *$ & $22.3 *$ & 34.9 \\
$\quad 60$ to 69 & 40.9 & 9.7 & 49.4 \\
Employment situation & & & \\
$\quad$ Working & $40.1 * *$ & $16.6 *$ & 43.3
\end{tabular}

\footnotetext{
${ }^{10}$ According to data provided by the ENADID 2009, elderly men are found primarily in nuclear households (50.2\%) while women are less so $(39.4 \%)$. Also we see that $15.8 \%$ of elderly women live alone whereas for men this arrangement is only $11.3 \%$.

11 Only three types of living arrangements were considered as dependent variable of the model: nuclear, extended and one-person. The co-residence household was not included since the number of cases was too low.

${ }^{12}$ In the multinomial model, marital status was not taken into account due to the fact that in one-person households people who are separated, divorced or widowed usually predominate; the category of married or cohabiting people showed few cases.
} 


$\begin{array}{llcc}\begin{array}{c}\text { Not working } \\ \text { Migrants at home }\end{array} & 41.5 & 11.1 & 47.4 \\ \quad \text { Yes } & 50.6 * & 7.7 * & 41.7 \\ \quad \text { No } & 40.8 & 13.0 & 46.2 \\ \text { Size of Locality } & & & 49.9 \\ >2500 \text { inhab. } & 37.9 * & 12.2 * & 43.0 \\ 2500 \text { to } 14,999 \text { inhab. } & 44.9 & 12.0 * & 43.2 \\ 15,000 \text { to } 999,999 \text { inhab. } & 44.5 & 13.3 & 45.7 \\ 100,000 \text { or more inhab. } & 41.0 & & \end{array}$

Source: Own calculations with National Survey of Demographic Dynamics (ENADID) 2009.

\section{Conclusion}

The National Survey of Demographic Dynamics is a source of useful information that can be used to understand family dimensions and living arrangements of the Mexican population over a determined period of time. It also allows for the identification of the most important changes within certain population groups, such as the elderly. Through this source of information for the years 1992, 1997, 2006 and 2009 some important changes in household configurations could be observed with special attention to households with elderly residents.

In this article we find important differences amongst household structures at national level, particularly households including individuals aged 60 and older. Our purpose was to identify the most relevant transformations derived from demographic aging and the reduction of fertility rates that had an impact on the household structure at both regional and national levels.

We found that Mexican households have shown a decrease in the prevalence of nuclear structure, our analysis shows no changes in extended households and an increase in households with non-family members, as well as a significant increase in one-person households. These kind of households (one - person) have gained popularity among the elderly population in the last years. Interestingly, contrary to observations in other countries where individuals of higher socioeconomic status live alone (Ramos, 1994), in Mexico, individuals from the lowest socioeconomic strata reside in these households. It is possible for this population to receive some sort of transference an attention from children living outside of the household or other family member and friends.

On the subject of change, in households including individuals aged 60 and older, there has been a slight increase in the presence of nuclear households (from 1992 to 2006); we believe this is to be, above all, a result of an increase in life expectancy. There has also been an increase in households composed of only a couple plus at least one elderly person. Although it is true that one-person households are not statistically significant on a national level, they become so when focusing on the elderly population. When compared at regional level, the concentration of the elderly in specific types of households' shifts; extended households have acquired a greater presence in most of the country's regions, especially in 2009. A similar behavior is found for one-person households, noting higher proportions of these types of living arrangements among the elderly in the North Eastern and the Yucatan Peninsula regions.

Certain households also exist where a double generational demand (older persons residing along with children under 5) is experienced. This is evidence of a new extended household with greater generational composition. It is to be assumed that in these households, support strategies will be developed when coping with the illness of elderly residents, and as a result the presence of either relatives or non-relatives will increase in these households.

The results of this study demonstrate the importance of highlighting the following aspects: in conceptual and methodological terms it is commonly recognized that the family is not only limited to households, but until now this is the best way to approach the study of families. However we see the urgency and necessity of having data sources that visualize families beyond the household and that show the complexities and dynamics of households. This would allow future research to hone in on families lives and support among family members. In relation to social policy and future research, the findings from this study suggest that programs and studies aimed at the adult population should consider not only greater economic factors (socioeconomic status, pension income, medical care, employment, etc.), but it is also important to take into account regional differences. As the findings of this study suggest, the older population has specific characteristics depending on the region in which it is located (poverty levels, fertility rates, mortality rates, infrastructure in the region, migration, size of locality, etc.); as well as individual aspects (age group, health status, etc.) and family (household type, family support and other social support).

\section{Acknowledgements}

This article was prepared with the financial support of the Regional Centre of Multidisciplinary Research 
(CRIM-UNAM). The authors wish to express their gratitude in the translation to Mrs. Susan Thomae and the careful reading of Eugenia Conde and Christopher Follett.

\section{References}

Ariza, M. \& Oliveira, O. de (2001). Familias en transición y marcos conceptuales en redefinición. Papeles de Población, 28(7), 9-39.

Ariza, M. \& Oliveira, O. de (2007). Familias, pobreza y desigualdad social en Latinoamérica: una mirada comparativa. Estudios Demográficos y Urbanos, 22(1), 9-42.

Borooah, V. K. (2002). Logit and probit: Ordered and multinomial models. Thousand Oaks, CA: Sage.

Consejo Nacional de Población (2006). Índices de marginación. Mexico City: Consejo Nacional de Población.

Caballero, M., Leyva-Flores, R., Ochoa-Marín S. C., Zarco, A., \& Guerrero, C. (2008). Las mujeres que se quedan: Migración e implicación en los procesos de búsqueda de atención de servicios de salud. Salud Pública de México, 50, 241-250. http://dx.doi.org/10.1590/S0036-36342008000300008

Comité Técnico para la Medición de la Pobreza [CTMP] (2002). Medición de la pobreza. Variantes metodológicas y estimación preliminar. Mexico City: Secretaría de Desarrollo Social.

Coward, R. \& Cutler, S. (1991). The composition of multigenerational households that include elders, Research on Aging, 1 (13), 55-73. http://dx.doi.org/10.1177/0164027591131003

Coward, R., Cutler, S., \& Schmidt, F. (1989). Differences in the household composition of elders by age, gender and area of residence. The Gerontologist, 29(6), 814-821. http://dx.doi.org/10.1093/geront/29.6.814

Echarri-Cánovas, C.J. (1995). Hogares y familias en México: Una aproximación a su análisis mediante encuestas de muestreo. Estudios Demográficos y Urbanos, 10(2), 245-293.

Esquivel, G. (1999). Convergencia regional en México, 1940 - 1995. El Trimestre Económico, 4, 725-761.

Ferring, D. (2009). Emotional relationship quality of adult children with ageing parents: On solidarity, conflict and ambivalence. European Journal of Ageing, 6(4), 253-265. http://dx.doi.org/10.1007/s10433-009-0133-9

García, B., Muñoz, H., \& Oliveira, O. de (1988). Hogares y trabajadores en la Ciudad de México. Mexico City: El Colegio de México / IIS-UNAM.

García, B. \& Rojas, O. (2002). Los hogares Latinoamericanos durante la segunda mitad del siglo XX: Una perspectiva sociodemográfica. Estudios Demográficos y Urbanos, 50, 261- 288.

Grundy, E. \& Henretta, J. (2006). Between elderly parents and adult children: A new look at the intergenerational care provided by the 'sandwich generation'. Ageing and Society, 26(5), 707-722. http://dx.doi.org/10.1017/S0144686X06004934

Gomes, C. (2007). Intergenerational Exchanges in Mexico: Types and Intensity of Support. Current Sociology, 55(4), 545-60. http://dx.doi.org/10.1177/0011392107077638

Gomes, C. \& Montes de Oca, V. (2004). Ageing in Mexico: Families, Informal Care and Reciprocity. In P. Lloyd-Sherlock (Ed.), Living Longer: Ageing, Development and Social Protection, (pp. 230 - 248). London: ZED Books.

González de la Rocha (2001). From resources of poverty to the poverty of resources? The erosion of a survival model. Latin American Perspectives, 28(4), 72-100. http://dx.doi.org/10.1177/0094582X0102800405

Instituto Nacional de Estadística y Geografía [INEGI] (1997). Los hogares en México, Mexico City: INEGI.

Instituto Nacional de Estadística y Geografía [INEGI] (2010). Mujeres y hombres en México 2010, Mexico City: INEGI.

Katz, R. (2009). Intergenerational family relations and subjective well-being in old age: A cross national study. European Journal of Ageing, 6(2), 79-90. http://dx.doi.org/10.1007/s10433-009-0113-0

López-Barajas, M. de la P., \& Izazola, H. (1994). El perfil censal de los hogares y las familias en México. Mexico City: Instituto Nacional de Estadística y Geografía/ Instituto de Investigaciones Sociales-Universidad Nacional Autónoma de México.

López-Ramírez, A. (2001). El perfil sociodemográfico de los hogares en México 1970 - 1997. Mexico City: Consejo Nacional de Población.

López-Ramírez, A. \& Lindstrom, D. (2008). Migración, remesas y arreglos residenciales de los adultos mayores en México. Estudios Demográficos y Urbanos, 23(3), 513-541.

Messmacher, M. (2000). Desigualdad Regional en México, el efecto del TLCAN y otras reformas estructurales 
(Documento de investigación núm. 2000 - 4). Mexico City: Dirección General de Investigación Económica, Banco de México.

Montes de Oca, V., \& Hebrero, M. (2006). Eventos cruciales y ciclos familiares avanzados: El efecto del envejecimiento en los hogares de México. Papeles de Población, 50, 97-116.

Montes de Oca, V., \& Hebrero M. (2008). Dinámica familiar, envejecimiento y deterioro funcional en México. Revista Kairós Gerontología, 11(1), 143-166.

Montes de Oca, V., Molina, A. \& Avalos, R. (2008). Migración, redes transnacionales u envejecimiento. Estudios de las redes familiares trasnacionales de la vejez en Guanajuato. México: Universidad Nacional Autónoma de México-Instituto de Investigaciones Sociales/ Gobierno del Estado de Guanajuato.

Montes de Oca, V. (coord.) (2008). Historias detenidas en el tiempo. El fenómeno migratorio desde la mirada de la vejez en Guanajuato. México: Gobierno del Estado de Guanajuato.

Montes de Oca, V. \& Garay, S. (2010). Familias, hogares y vejez: Cambios y determinantes en los arreglos familiares con personas adultas mayores en México, 1992-2006. In A. M. Chávez-Galindo, \& C. Menkes (Eds.), Procesos y tendencias poblacionales en el México contemporáneo. Una mirada desde la ENADID 2006. Mexico City: Secretaría de Salud/ Centro Regional de Investigaciones Multidisciplinarias de la Universidad Nacional Autónoma de México.

Oliveira, O. de, (1988). Unidades domésticas y familias censales. DEMO, Carta demográfica sobre México, 1, 22-23.

Palloni, A., Pinto, G., \& Wong, R. (June 2009). Family Support Networks and Population Ageing. Paper presented in seminar on family Support Networks and Population Aging, Doha International Institute for Family Studies and Development, UNFPA and Institute for Policy Research, Northwestern University in Qatar.

Pérez-Amador, J., \& Brenes, G. (2006). Una transición en edades avanzadas: Cambios en los arreglos residenciales de adultos mayores en siete ciudades Latinoamericanas. Estudios Demográficos y Urbanos, 21(3), 625-661.

Rabell, C., \& Murillo, S. (2010). El respeto y la confianza: Prácticas y percepciones de las familias numerosas y pequeñas. In C. Rabell (coord.), Tramas familiares en el México contemporáneo. Una perspectiva sociodemográfica (pp. 293-350). Mexico City: Instituto de Investigaciones Sociales-Universidad Nacional Autónoma de México/ El Colegio de México.

Ramos, L. (1994). Family support for the elderly in Latin America: The role of the multigenerational household. In United Nations, Ageing and the Family: Proceedings of the United Nations International Conference on Aging Populations in the context of the Family. New York: Department for Economic and Social Information and Policy Analysis.

Rentería, E., Maldonado, C., \& Lanza, B. (2007). Abuelos y nietos, ¿una convivencia beneficiosa para los más jóvenes? El caso de Brasil y Perú. Papeles de Población, 52, 47-75.

Reyes, L. (2008). Diagnóstico sociodemográfico de los adultos mayores indígenas de México. Mexico City: Comisión Nacional para el Desarrollo de los Pueblos Indígenas.

Ruíz-Pantoja, T.E. (2008). Diferencias en la geografía del envejecimiento en México. Paper presented at the IX Reunión de Investigación Sociodemográfica, Mérida, Yucatán, Mexico.

Tuirán, R. (1996). Las trayectorias de vida familiar en México: Una perspectiva histórica. Hogares, familias: Desigualdad, conflicto, redes solidarias y parentales, Mexico City: Sociedad Mexicana de Demografía.

United Nations. (1994). Ageing and the Family: Proceedings of the United Nations International Conference on Aging Populations in the context of the Family, New York: Department for Economic and Social Information and Policy Analysis.

Varley, A., \& Blasco, M. (October 1999). 'Reaping what you sow'? Older Women, Housing and Family Dynamics in Urban México. Paper presented in the XXII Congreso de la Asociación Latinoamericana de Sociología, Concepción, Chile.

Wilhite, B.C. (1994). Leisure in Daily Life. Journal of Park and Recreation Administration, 12(4), 64-78.

\section{$(\mathrm{cc}) \mathrm{Br}$}

This work is licensed under a Creative Commons Attribution 3.0 License. 